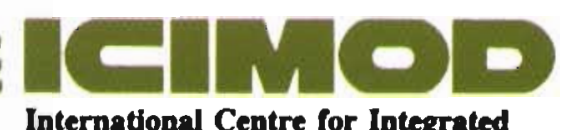

International Centre for Integrated

Mountain Development

\title{
HYDROLOGICAL ASPECTS OF THE HIMALAYAN REGION
}

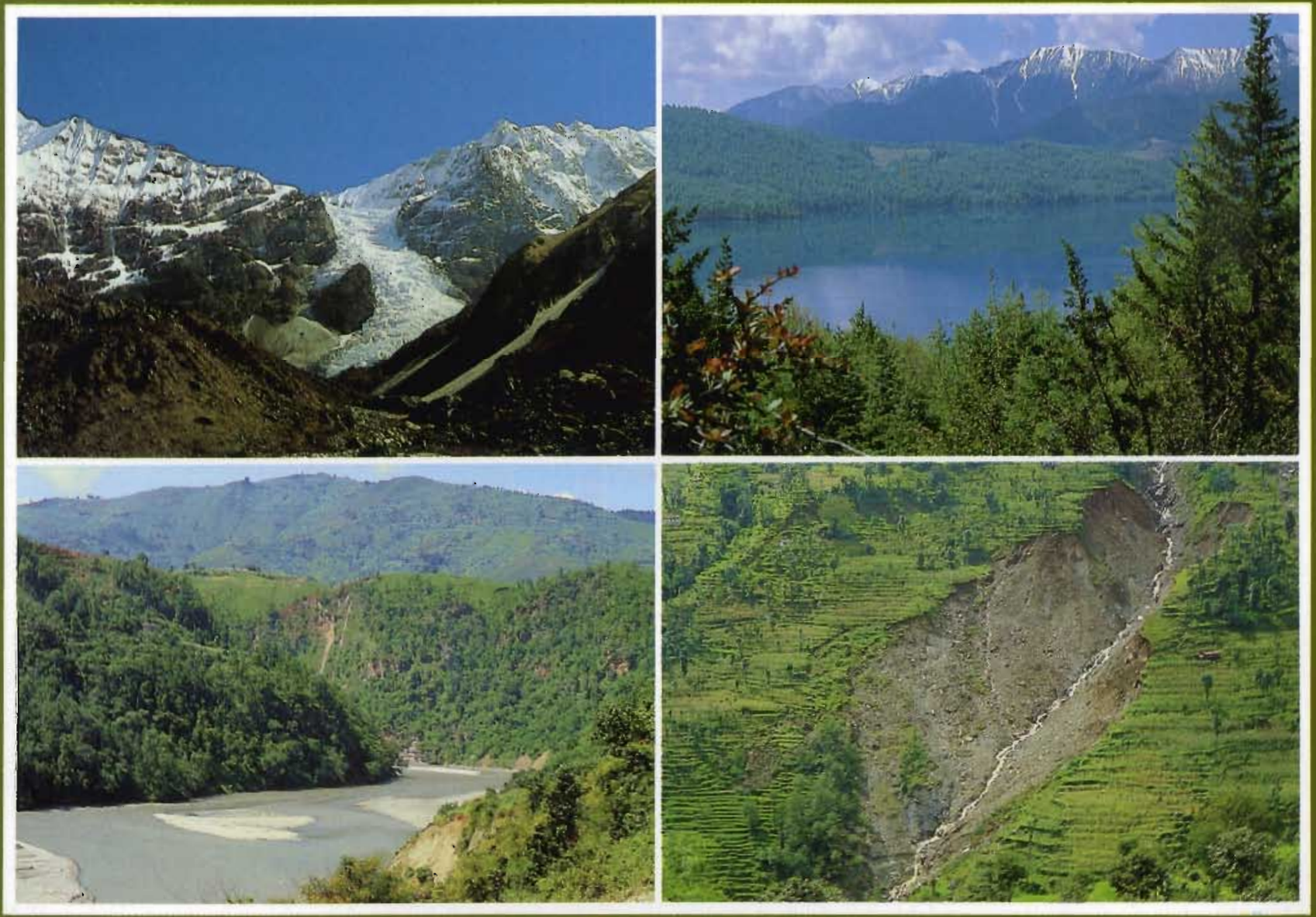

Donald Alford

ICIMOD OCCASIONAL PAPER NO. 18

Kathmandu, NEPAL

1992 


\section{ICIMOD Occasional Papers}

No. 1 EROSION AND SEDIMENTATION PROCESSES IN THE NEPALESE HIMALAYA Brian Carson (1985)

No. 2 INTEGRATED RURAL DEVELOPMENT PROJECTS IN NEPAL: A REVIEW Bharat B. Pradhan (1985)

No. 3 SUSTAINING UPLAND RESOURCES: PEOPLE'S PARTICIPATION IN WATERSHED MANAGEMENT

Anis Dani and J.G. Campbell (1986)

No. 4 DECENTRALIZED ENERGY PLANNING AND MANAGEMENT FOR THE HINDU KUSHHIMALAYA

Deepak Bajracharya (1986)

No. 5 GLACIAL LAKE OUTBURST FLOODS AND RISK ENGINEERING IN THE HIMALAYA Jack D. Ives (1986)

No. 6 OPERATIONAL EXPERIENCES IN FOREST MANAGEMENT DEVELOPMENT IN THE HILLS OF NEPAL

G.B. Applegate and D.A. Gilmour (1987)

No. 7 FORESTRY-FARMING LINKAGES IN THE MOUNTAINS

T.B.S. Mahat (1987)

No. 8 ROAD CONSTRUCTION IN THE NEPAL HIMALAYA:

THE EXPERIENCE FROM THE LAMOSANGU-JIRI PROJECT

Urs Schaffner (1987)

No. 9 MOUNTAIN ENVIRONMENTAL MANAGEMENT IN THE ARUN RIVER BASIN OF NEPAL John R. Dunsmore (1988)

No. 10 HILL AGRICULTURE AND THE WIDER MARKETING ECONOMY:

TRANSFORMATION PROCESSES AND EXPERIENCE OF THE BAGMATI ZONE IN NEPAL Mahesh Banskota (1989)

No. 11 HIGHLAND-LOWLAND INTERACTIONS IN THE GANGES BRAHMAPUTRA RIVER BASIN: A REVIEW OF PUBLISHED LITERATURE

L.A. Bruijnzeel and C.N. Bremmer (1989)

No. 12 MICRO-LEVEL ENVIRONMENTAL MANAGEMENT OBSERVATIONS ON PUBLIC AND PRIVATE RESPONSES IN KAKANI PANCHAYAT, NEPAL

Saroj K. Basnyet (1989)

No. 13 MOUNTAIN ENVIRONMENTAL MANAGEMENT: NYEMO COUNTY (TIBET), CHINA Zhang Rongsu (1989)

No. 14 NATURAL RESOURCE MANAGEMENT IN THE MOUNTAIN ENVIRONMENT: EXPERIENCES FROM DOON VALLEY, INDIA

J. Bandyopadhyay (1989)

No. 15 LANDSLIDE MANAGEMENT IN THE MOUNTAIN AREAS OF CHINA Li Tianchi (1990)

No. 16 MINI- AND MICRO-HYYROPOWER IN NEPAL Jean-Marion Aitken, G. Cromwell, and G. Wishart (1991)

No. 17 AGROFORESTRY IN MOUNTAIN AREAS OF THE HINDU KUSH-HIMALAYAN REGION Jeannette Denholm (1991) 


\section{Hydrological Aspects of the Himalayan Region}

Donald Alford

ICIMOD OCCASIONAL PAPER No. 18

Published by

International Centre for Integrated Mountain Development Kathmandu, Nepal 
Copyright $\stackrel{\odot}{ } 1992$

International Centre for Integrated Mountain Development

All rights reserved

Cover photograph: Top Left: Langtang Himal, Nepal

Top Right: Rara Lake, Mugu, Nepal

(Both courtesy of S.R. Chalise)

Bottom Left: Trisuli River, Mugling Road, Nepal

Bottom Right: Stream Off the Jiri Road, Nepa

(Both courtesy of S.R. Chalise)

Published by

International Centre for Integrated Mountain Development

G.P.O. Box 3226 ,

Kathmandu, Nepal

ISBN 92-91 15-399-0

Typesetting at ICIMOD Publications' Unit

Printed at Nepal Lithographing Co.

Lazimpat plaza, Lazimpat, kathmandu.

Phone:- 415564

The views and interpretations in this paper are the author's and are not attributable to the International Centre for integrated Mountain Development (ICIMOD), and do not imply the expression of any opinion concerning the legal status of any country, territory, city or area of its authorities, or concerning the delimitation of its frontiers or boundaries. 


\section{Foreword}

This paper was initially prepared by the author for the "International Symposium on Mountain Environmental Management in the Hindu Kush-Himalayan Region", which was organised jointly by ICIMOD and UNESCO/MAB at ICIMOD Headquarters during April 1989. It was subsequently revised by the author in its present form. This paper deals essentially with two major aspects of water resources in the Himalayas, viz, (i) the impact of human use of the natural environment on the hydrological regime of watersheds in the Himalayas, and (ii) analysis of existing data of the Kosi Watershed of Eastern Nepal, as an illustration of examination of the interactions that have an impact on the water budget of a mountain watershed in the Region. As the author has pointed out, 'primary data describing water resources are essentially unavailable for the Hindu Kush-Himalayan Region'. However, it is also seen that even available data have not been well analysed to understand the hydrological aspects of major or minor rivers in this Region.

It is hardly necessary here to emphasise the importance of water resources in the overall development of the Hindu Kush-Himalayan Region. As the world's highest towers of snow and ice, the Himalayas are also the largest storehouse of fresh water and sources of such mighty rivers as the Indus, Ganges, Brahmaputra, and Mekong. As the abode of snow, as their very name suggests, they have not only been the sources of these mighty and perennial rivers but have been the sustaining sources of major ancient civilisations in these river basins also.

Despite the vast regional potential for development of water resources for multifarious uses, scientific understanding of the complex interaction between natural forces and human impact on the hydrologic regimes in these highly energised and sensitive mountain environments are far from adequate. Furthermore, the unique combination of extreme factors, such as intense seasonal precipitation and highly steep topography due to a sharp rise in altitude within a narrow width, has not only inhibited the collection of data in the difficult mountain watersheds, but has also placed serious limitations on the use of standard hydrological principles, techniques, and models which are basically developed in the more temperate and less extreme environments of Europe and North America. Thus it is not possible to apply general solutions developed elsewhere to the hydrological problems of the Region, as is emphasised by the author in his conclusions. The paper also indicates that simple models could probably be developed to deal with such problems and improve the use of resources for development.

I am happy to say that ICIMOD is already engaged actively, jointly with the UNESCO/IHP and in cooperation with national institutions of the participating countries of ICIMOD and the WMO, in developing a Regional Programme on Mountain Hydrology in the Hindu Kush-Himalayan Region. This joint initiative has been welcomed by all concerned.

In the above context, I hope that the publication of this paper will help towards a better appreciation of the problems associated with proper understanding of the hydrological processes in the Himalayas which affect both the uplands and lowlands in the Region. It might also help towards realisation of the urgent need for regional cooperation and international support for the ongoing and proposed programmes on hydrological studies in the Region, such as the one already initiated jointly by ICIMOD and UNESCO/IHP. It is also hoped this publication will be of use not only to hydrologists but also to all those who have interest in the development of water resources in these complex mountain environments. 


\section{Preface}

The countries of South Asia -- Pakistan, India, Nepal, Bhutan, and Bangladesh -- are dependent to varying degrees on the annual cycle of water flowing into, through, and from Himalayan and Trans-Himalayan mountain ranges. Though water resources of South Asia are of obvious importance in the development of the region, the flow of water through Himalayan watersheds has received almost no serious scientific consideration.

In general, mountain hydrologic systems are relatively unstudied. Where studies have been undertaken, as in the European Alps or the mountains of western North America, only a few workers have attempted regional generalisations. Most of the information has been presented as site-specific studies of individual basins. The bulk of the results discussed in the technical literature has been obtained from so-called "black-box" studies of basins of relatively small size. Such studies commonly consider only a single relationship; such as that between changes in vegetation cover and the resulting changes in streamflow or sediment transport. Such studies lump all other controls on the water or sediment balance together as an unstudied variable -- the "black-box". Blackbox studies are very difficult to generalise. It is often the case that factors that are critical in determining variations in the water or sediment budget of a basin -- such as climate -- are varying simultaneously with the control under study.

The initial impetus for the present study was provided by a request from Dr. Colin Rosser, the former Director of ICIMOD, to prepare a paper on water resources and environmental management for a Workshop on Mountain Environmental Management, jointly sponsored by ICIMOD and UNESCO/MAB. Both the purposes of the workshop and the nature of this paper changed over the course of time. From a study of the role of environmental management in managing the water resources of the Hindu Kush-Himalayan Region, the focus of the study gradually narrowed to a consideration of the hydrometeorological aspects of a smaller part of the region -- the Nepal Himalayas. The final result reflects concerns that existed or evolved during the preparation of the paper, namely that:

- the relationship between human use of the natural environment and subsequent changes in the hydrologic regime of Himalayan watersheds has not been well-defined; and

- the existing data bases describing this relationship for the region have not been analysed in any meaningful way.

This paper represents an attempt to consider the water resources of the Himalayan Region from these two aspects: (1) what are the basic interactions that determine the water budget of a mountain watershed in the region and, specifically, (2) what do the data bases tell us about the nature of these budgets? In many ways, these are not compatible topics. A consideration of basic water budget interactions in any environment involves a discussion of the most elementary hydrometeorological and geomorphological principles, while an analysis of the existing data bases represents a higher level of sophistication. Of necessity, this means that the paper will contain aspects of interest to at least two very different audiences. I hope that readers from both professional and lay audiences will recognise the needs of the other, as well as the fact that far too much time has passed without any serious discussion of either aspect of the problem of water resources' development in the mountains of South Asia. 
For a variety of reasons, primary data describing water resources are difficult to obtain for the Hindu KushHimalayan Region. This paper, therefore, is based almost exclusively on secondary sources of information. Emphasis has been placed on the nature of the concepts associated with the interpretation of water resources' data and the bulk of the references cited in the text deal with the literature describing these concepts in more detail. In almost all cases, references are only single illustrative examples of an extensive literature describing the sciences of hydrology, climatology/meteorology, and fluvial geomorphology. They are included primarily to direct the interested reader to this literature. The discussion of the water resources of eastern Nepal is based upon specific data available in publications of the Government of Nepal.

Much of the data upon which this study is based were assembled and organised during the Spring of 1989, during which time the political differences between India and Nepal forced a virtual closing of ICIMOD. The bulk of the manuscript, therefore, has been written from my home in Montana, USA. I would like to thank Dr. Colin Rosser for making this study possible. I am particularly grateful to Prof. Suresh Raj Chalise for his patient encouragement. Thanks, too, to Dr. Corneille Jest who helped me keep my sense of perspective. In fact, there are far too many people who helped me through the data collection phase of this study to be listed, and I hope that each of them remembers something of what we shared.

Donald Alford 


\section{Table of Contents}

Page

\section{Foreword}

Preface

$\begin{array}{ll}\text { I. Introduction } & 1\end{array}$

Water Resources and Environmental Management $\quad 1$

$\begin{array}{lr}\text { Uncertainty } & 2\end{array}$

II. Mountain Hydrologic Interactions 4

The Mountain Watershed $\quad 4$

$\begin{array}{ll}\text { Water and Energy Budgets } & 5\end{array}$

Erosion and Sediment Transport $\quad 7$

III. Environmental Interrelationships 10

$\begin{array}{lr}\text { Geology } & 10\end{array}$

$\begin{array}{lr}\text { Climate } & 11\end{array}$

$\begin{array}{lr}\text { Topography } & 12\end{array}$

$\begin{array}{lr}\text { Relief } & 12\end{array}$

$\begin{array}{lr}\text { Slope } & 12\end{array}$

Aspect

$\begin{array}{ll}\text { Vegetation } & 13\end{array}$

IV. Macro-scale Hydrology of the Hindu Kush-Himalayan Region 16

$\begin{array}{ll}\text { The Indus Basin } & 16\end{array}$

$\begin{array}{lr}\text { Climate } & 16\end{array}$

$\begin{array}{lr}\text { Streamflow } & 18\end{array}$

$\begin{array}{lr}\text { The Ganges Basin } & 19\end{array}$

$\begin{array}{lr}\text { Climate } & 20\end{array}$

$\begin{array}{lr}\text { Streamflow } & 20\end{array}$

$\begin{array}{lr}\text { The Yalu Zangbu-Brahmaputra Basin } & 21\end{array}$

$\begin{array}{lr}\text { Climate } & 21\end{array}$

$\begin{array}{ll}\text { Streamflow } & 21\end{array}$

Regional Values of Erosion and Sediment Transport $\quad 23$

$\begin{array}{lr}\text { The Upper Indus Basin } & 23\end{array}$

$\begin{array}{ll}\text { The Ganges Basin } & 24\end{array}$

The Yalu Zangbu Basin $\quad 24$

\begin{tabular}{|l|l} 
Glaciers of the Hindu Kush-Himalayan Region & 25
\end{tabular} 
$\begin{array}{lr}\text { The Database } & 29\end{array}$

$\begin{array}{lr}\text { Analytical Procedures } & 35\end{array}$

$\begin{array}{lr}\text { Results } & 39\end{array}$

$\begin{array}{lr}\text { Climate } & 39\end{array}$

$\begin{array}{ll}\text { Air Temperature } & 39\end{array}$

$\begin{array}{lr}\text { Precipitation } & 40\end{array}$

$\begin{array}{lr}\text { Evaporation } & 42\end{array}$

$\begin{array}{lr}\text { Topography } & 42\end{array}$

Streamflow and Specific Runoff $\quad 45$

$\begin{array}{lr}\text { Streamflow and Climate } & 45\end{array}$

$\begin{array}{lr}\text { Streamflow and Basin Surface Area } & 48\end{array}$

$\begin{array}{lr}\text { The Annual Hydrographs } & 49\end{array}$

Temporal Variations in Streamflow Volume $r$

$\begin{array}{lr}\text { Snow Hydrology } & 58\end{array}$

$\begin{array}{lr}\text { Variations in Runoff with Altitude } & 59\end{array}$

$\begin{array}{ll}\text { VI. Summary and Discussion } & 63\end{array}$

\section{References}

\section{List of Figures}

1: The Relationship among Elements of the Water Budget of a Region or a Catchment Basin 6

2: The Sediment Load of Selected South Asian Rivers Compared to the World Average 7

3: The Complex Paths Followed by Sediment from the Point of Production by Erosion to the Mouth of a Catchment Basin

4: The Altitudinal Zonation of Ecosystems in the Karakoram Range of the Western Hindu Kush-Himalayan Region

5: The Altitudinal Zonation of Ecosystems in the Himalayan Mountains of Nepal 15

6: A Sketch Map Showing the Mountain Catchments of the Upper Indus Basin 17

7: A Sketch Map of the Mountain Catchments of the Ganges River Basin 19

8: The Yalu Zangbu-Brahmaputra Basin Showing the Lower Limit of the Mountain Portion of the Basin

9: Three of the Major Tributaries to the Ganges River Originate in the Nepalese Himalayas: the Ghaghara (Karnali), the Gandaki (Narayani), and the Kosi

10: Gauged Sub-basins of the Karnali River for which Data Were Used in This Study 30

11: Gauged Sub-basins of the Narayani River for which Data Were Used in This Study 31

12: Gauged Sub-basins of the Sapta Kosi River for which Data Were Used in This Study 32

13: A Schematic Representation of the Altitudinal Zonation Used in this Study to Derive Incremental Volumes of Streamflow

14a: A Schematic Representation of the Annual Hydrograph, Showing the Composition of the Rising and Falling Limbs

14b: A Semi-Log Plot of the Relationship Between Quickflow and Baseflow during the Recession Phase of the Annual Hydrograph

$\begin{array}{lll}\text { 15: The Relationship between Annual and Seasonal Air Temperatures and Altitude } & 40 \\ \text { 16: A Five-year Running Mean of Precipitation in Kathmandu for the Period 1921-1985 } & 41\end{array}$

17: The Distribution of Precipitation with Altitude in the Karnali Basin Shows No Distinct Orographic Trend

18: There is Some Suggestion of An Orographic Gradient of Precipitation in the Narayani Basin, Represented by the Formline

19: While There is Considerable Scatter, Maximum Values of Precipitation in the Sapta Kosi Basin Occur Between 1,500-2,500 m, while Minimum Values are Recorded at the Highest and Lowest Altitudes for which Data are Available 
20: Hypsometric Curves Showing Distribution of Surface Area with Altitude in the Dudh Kosi,

Kali Gandaki, and Upper Karnali Basins

21: North-south Transects through: a. The Karnali Basin at Long. $83^{\circ} 10^{\prime}$, b. The

Narayani Basin at -Long. $84^{\circ} 10^{\prime}$, and c. The Sapta Kosi Basin at Long. 87. 20'

22: The Annual Distribution of Precipitation and Runoff in the Sapta Kosi Basin Follow Very

Similar Trends

23: Monthly Relationship between Precipitation and Runoff in the Bagmati Basin

24: The Relationship between Annual Precipitation and Specific Runoff for the Bagmati Basin for the Period of Record

25: Basin Surface Area Is Not a Good Index of Mean Annual Streamflow

26a. The Relationship between Streamflow and Specific Runoff for the Seti River in the Karnali Basin

26b. The Relationship between Streamflow and Specific Runoff for the Kali Gandaki in the Narayani Basin

26c. The Relationship between Streamflow and Specific Runoff for the Tamur River in the Sapta Kosi Basin

27: The Relationship between Streamflow and Specific Runoff, mm

28: Recession Curves for Representative Basins in the Sapta Kosi, Narayani, and Bagmati Subbasins

29: The Hydrograph of the Dudh Kosi River

30: Monthly Mean and Extreme Streamflow Volumes in the Balephi Khola, Characteristic of the Extremes of Himalayan Rivers

31: Average Monthly Streamflow Volume for the Balephi Khola and Bagmati River, Showing the Extreme Range of Flows Characterising Individual Years

35: Based Upon the Sum of Peak Annual Flows for the Major Rivers of Nepal

36: While there is considerable scatter, the correlation between per cent contribution of Nepali tributaries to the peak annual flow of the Ganges River appears to be negative. This suggests that the Nepali rivers modulate, rather than contribute negatively to, the flow of the Ganges

37: The relationship between peak annual flows and mean annual flows is positive, suggesting that the latter may be used as an index to the contribution of Nepali tributaries to the flood-drought cycles of the Ganges basin

38: The Relationship between Mean Basin Altitude, Z, m, and Specific Runoff, Qs, mm, for the Subbasins of the Karnali River

39: The Relationship between Mean Basin Altitude, Z, m, and Specific Runoff, Qs, mm, for the Subbasins of the Narayani River

40: The Relationship between Mean Basin Altitude, $\mathrm{Z}, \mathrm{m}$, and Specific Runoff, Qs, mm, for the Subbasins of the Sapta Kosi River

41: The Three Major Hydrological Environments Described by Equations (6)-(10) in the Text

\section{List of Tables}

1: Hydrometric Stations and Streamflow Measurements -- Upper Indus Basin

Hydrometric Stations and Streamflow Measurements -- Upper Ganges Basin

Hydrometric Stations and Streamflow Measurements - Yalu Zangbu Basin

Measured Values of Sediment Transport -- Mountain Rivers of South Asia

Selected Hydrometric Stations of Nepal

Selected Climatological Stations and Mean Annual Precipitation - Nepal

Area-altitude Relationships in the Sub-basins of Nepal

Mean Monthly and Annual Air Temperatures for Eastern Nepal

Mean Monthly and Annual Evaporation Measurements for Eastern Nepal

10: Streamflow and Runoff Statistics for the Karnali Basin -- Western Nepal

12: Streamflow and Runoff Statistics for the Sapta Kosi Basin -- Eastern Nepal

Maximum Monthly Discharge $\left(\mathrm{m}^{3} / \mathrm{s}\right)$ Values for the Ganges River and Major Nepalese Tributaries

14: Streamflow and Runoff Statistics for Glacierised Basins of the Upper Dudh Kosi River -- 1984

15: Calculated and Measured Values of Streamflow

16: Representative Calculations, Distribution of Runoff with Altitude in Selected Sub-basins of the Nepalese Himalayas 